\title{
Narratives of Expansion, Last Wills, Poor Expectations and the Conquest of Seville (1248)
}

\author{
(in John HUDSON, Sally CRUMPLIN (eds.), \\ The Making of Europe. Essays in Honour of Robert Bartlett. Brill, Leiden. pp.123-141)
}

Ana Rodríguez

Instituto de Historia

CCHS-CSIC

Madrid (Spain)

In his The Making of Europe Robert Bartlett reflected in depth on the fact that "Between 950 and 1350 Latin Christendom roughly doubled in area and, while this religious expansion did not always involve either conquest or immigration, it often did". ${ }^{1}$ If this is clearly a characteristic of the formation of Europe in the Middle Ages, the Iberian Peninsula and its constituent kingdoms are a particularly suitable laboratory to analyse a process of expansion of similar extent but conducted over a remarkably short period of time. In July 1212 the Castilian armies led by King Alfonso VIII defeated the Almohads of the Caliph al-Nasir in the pitched battle of Las Navas, a victory that for the Christians effectively meant the opening of access to the territories of present-day Andalusia, which had been in Muslim hands for five centuries. In December 1248 the triumphant armies of Ferdinand III, grandson of Alfonso VIII, entered the emblematic Muslim city of Seville. In the course of barely 36 years, the territory of the kingdom of Castile had increased in size by nearly half; in fact, it had almost doubled if we take into account that in 1230 the king of Castile had inherited the kingdom of Leon on the death of his father Alfonso IX, as well as the Leonese conquests from the Muslims on the western border with Portugal. ${ }^{2}$

There is no doubt that the consequences of conquests had already been felt in the Iberian Peninsula for centuries. The exploitation of new areas took various forms, depending on the chronology, the type of grant by royal authority, and the pre-existing demographic and economic structure. After the conquest of Toledo by Alfonso VI in

\footnotetext{
${ }^{1}$ Robert Bartlett, The Making of Europe: Conquest, Colonization, and Cultural Change, 950-1350, p. 292.

${ }^{2}$ Grosso modo, the territory of Castilla occupied about $162,000 \mathrm{~km}^{2}$ of the surface of the Peninsula, and that of Leon, 109,000 km². Territory conquered between 1212 and 1248 amounted to about $80,000 \mathrm{~km}^{2}$.
} 
1085 the basic problem facing the Castilian monarchs was occupying great tracts of land very close to the major Muslim cities; to these it was not easy to attract Christian settlers. The territorial gains became more and more concentrated in the hands of new beneficiaries, such as the Military Orders, particularly those of Santiago, Calatrava, and Alcántara, which had firmly established themselves on Spanish soil thanks to decisive royal support, and which had devoted the greater part of their efforts to the conquest of Al-Andalus. This led to a model of settlement in which the inhabited areas were few and far between, with large areas of land given over to pasture, used by migratory flocks that came down from the northern kingdom in the winter months. ${ }^{3}$

The impact of the conquests was greater from the final decades of the twelfth century, when the momentum of conquest not only increased but was led almost exclusively by the Christian kings. This momentum, from 1212 onwards, put into Christian hands great areas capable of being settled, colonized and exploited economically. Since the conquest had been on the orders of the kings, the kings handed out the territories to their armies and subjects, occasionally allowing defeated Muslims to remain as cultivators in rural holdings once they had lost their lands. The beneficiaries of this great expansion were again the Military Orders, some of the most powerful noble houses, and the major frontier bishoprics, keen to incorporate new lands and rents into their dioceses. In addition, some municipal councils that had taken an active part - providing money and men, according to the regulations laid out in the fueros - received land in the territories won from Al-Andalus. A new system was then put into practice by the monarchs, and the so-called repartimientos, or distributions of land, became a more common and efficient way of translating Christian military achievements into the incorporation and organization of conquered territory. As will be illustrated with the case of Seville, the purpose was to encourage the massive settlement of colonists in the new territories colonists coming in the main from the victorious kingdoms themselves - as well as to reward those who had shouldered the burden of the campaigns. The process involved a re-ordering of space which, as the term repartimiento implies, was distributed among a complex social group, whose members ranged from small peasants to great lords.

\footnotetext{
${ }^{3}$ An excellent synthesis in Hilario Casado, "La economía de las Españas medievales (c. 1000-c. 1450)," in Historia económica de España, siglos X-XX, ed. Francisco Comín et al. (Barcelona, 2002), pp. 14-22.
} 
Various circumstances caused the distribution operations to multiply over the years, and their results were far from stable and definitely not final. ${ }^{4}$

The process of expansion in the transition from the twelfth to the thirteenth centuries was distinguished by the increasing power of the monarchy in the territorial organization and political construction of the Christian kingdoms of the Peninsula. A strong ecclesiastical network, with ample resources and headed by powerful bishops achieved - as The Making of Europe rightly comments - considerably greater scope than did those of the rest of Europe. It was also characterized by low demographic pressure on the land and resources, and by the importance of a "war economy" which generated an enormous, albeit irregular, flow of wealth and cash, all dependent on the relations between the kings and the nobility of their kingdoms. The Iberian experience of the twelfth and thirteenth centuries, in certain respects corresponding with that of some other European Christian kingdoms, set up diverse models of political, economic and social integration which would be manifest throughout the Later Middle Ages. ${ }^{5}$

In the following pages this process of expansion is tackled from three complementary perspectives. The first deals with the construction of an epic narrative on the conquest of Seville in 1248, the epitome of the final defeat of Al-Andalus, which created the historiographical perception - not supported by other contemporary sources - of an exceptional event differentiated from other military campaigns. The second deals with the transformation of the property and settlement structures around Seville recorded in the Libro del Repartimiento (Book of Apportionment) as a consequence of the distribution of the war profits. The third deals with the perception of both processes the conquest and the sharing of benefits - moulded through the experience of some of their actors coming from the areas most remote from the war-zone.

(i) Seville, a Christian narrative

4 Pascual Martínez Sopena, "Poblar y repartir en el siglo XIII. Expertos y experimentación en la corona de Castilla”, in Expertise et valeur des choses au Moyen Âge. Savoirs, écritures, objets, ed. Laurent Feller and Ana Rodríguez (forthcoming, Madrid, 2015).

${ }^{5}$ Ana Rodríguez, "Spain", in Agrarian Change and Crisis in Europe, ed. Harry Kitsikopoulos, 1200-1500 (New York, 2011), pp. 167-203. 
The arrival of the Christians in Seville was the culmination of the great process of expansion that followed the victory of King Alfonso VIII of Castile at Las Navas in 1212. In 1236, in an unstoppable advance begun shortly after the accession of Ferdinand III, the Christians entered Cordoba, the main city of Al-Andalus, where the Caliphal power had left its lasting artistic and cultural mark. From there they continued on their way, leading to the long siege and surrender of Seville twelve years later, in 1248. The conquest of these two cities, both strongholds of the legitimacy of the past and the present of Al-Andalus, represented a founding moment in the construction of the image of the royal achievements, and one that would be firmly anchored in a new narrative of the Christian re-conquest that endured into modern historiography.

The solemn entry of Ferdinand III into Cordoba in late June 1236, accompanied by the nobility and ecclesiastics of the kingdom, together with the conversion of the mosque built in the ninth century and subsequently extended up to the time of Almanzor - into a Christian church after ritual purification and stripping of its Islamic past, formed a powerful image of the Christian victory. The conquest of Cordoba was a unique event and one of undeniable symbolic value. The memory of the entry of the hosts of Ferdinand III was maintained in the dating of documents issued by the royal chancery for two years, between July 1236 and July 1238: the clause secundo uidilicet anno quod ego rex Ferrandus obsedi Cordubam, famosissimam ciuitatem, et cooperante immo penitus faciente gratia Spiritus Sancti per laborem meum reddita est cultui christiano, can be found at the end of a document dated September 1237 and issued by the royal chancery in Burgos. ${ }^{6}$

The value of the conquest of Cordoba, both real and symbolic, was partly a consequence of the extraordinary historiographical activity that developed precisely at that moment in the kingdoms of Castile and Leon, and this was also a fundamental factor in the remarkable propagation of this event throughout the Christian world. In a very short time - and after a twelfth century with something of a dearth of historiography - three chronicles of extraordinary importance appeared: the Chronicon

\footnotetext{
${ }^{6}$ Reinado y diplomas de Fernando III, ed. Julio González, (Cordoba, 1986), 3.doc. 609, 136-138. It was not the first time that the chancery had become a mouthpiece for royal success: the use of the memory of the conquest in royal documentation had a long tradition in Castile, as can be seen in the propaganda work of the chancery manifest in the dating of the documents of Alfonso VIII following the victory of 1212 .
} 
Mundi by Luc of Tuy; De Rebus Hispaniae, written by the Archbishop of Toledo, Rodrigue Jimenez of Rada, and finally the so-called Chronica Regum Castellae, attributed to John of Soria, Ferdinand III's royal chancellor. ${ }^{7}$ All three conclude with the taking of Cordoba, giving meticulous accounts of the military campaign, of the entry of the king and his armies, and of the conversion of the mosque into a cathedral. Hardly any subsequent event caught the attention of these three writers, despite the fact that they all lived for some time after putting an end to their accounts, and that conquests were continuing at a dizzying pace. There have been several explanations for this lack of interest. ${ }^{8}$ Whatever the reason, the conquest of the Ummayad city - perhaps due to the rapid and early circulation of some of these chronicles- had an immediate impact on historiography outside the Iberian Peninsula. ${ }^{9}$ The fall of Cordoba thus became a key event in the construction of the contemporary narrative of the defeat of Islam at the hands of the Christians.

\footnotetext{
${ }^{7}$ The Chronicon Mundi, a universal history written between 1232 and 1236 by Luc of Tuy, a canon of San Isidoro in Leon, commissioned by Queen Berengaria, the mother of Ferdinand III; De Rebus Hispaniae, another history of the world, written between 1237 and 1243 by the Archbishop of Toledo- holder of the most economically and politically powerful ecclesiastical see of all the Christian kingdoms of the Peninsula -at the request of King Ferdinand III; and the so-called Chronica Regum Castellae, attributed to John of Soria, Bishop of Osma, Ferdinand III's royal chancellor, and written at two different times between 1230 and 1236. Lucas Tudensis, Chronicon Mundi, ed. Emma Falque, Corpus Christianorum. Continuatio Medievalis 74 (Turnhout, 2003); Rodericus Ximenez de Rada. Historia de Rebus Hispaniae, ed. Juan Fernández Valverde, Corpus Christianorum. Continuatio Medievalis 72 (Turnhout, 2003); Chronica Latina Regum Castellae, ed. Luis Charlo Brea, Corpus Christianorum. Continuatio Medievalis 73 (Turnhout, 2003). See, among others, Ana Rodríguez, "La preciosa transmisión. Memoria y Curia Regia en Castilla en la primera mitad del siglo XIII”, in La construcción medieval de la memoria regia, ed. Pascual Martínez Sopena and Ana Rodríguez (Valencia, 2011), 295-324.

${ }^{8}$ The relationship between the exact moment of writing of the chronicles and the fear of the Church's restoration of old Visigoth sees that could be foreseen in view of the advance of Ferdinand III's armies, and which might pose a threat to the interests of the cathedral of Toledo or the episcopal city of Leon, has also been highlighted by Peter Linehan, History and the Historians of Medieval Spain (Oxford, 1993).

${ }^{9}$ The conquest of Cordoba had an immediate effect on contemporary historiography, mentioned, among others, in the Chronica Majora of the monk Matthew Paris and the chronicle of Alberic of Trois-Fontaines. Ana Rodríguez, La consolidación territorial de la monarquía feudal castellana. Expansión y fronteras durante el reinado de Fernando III (1218-1252) (Madrid, 1994); Derek K. Lomax, "La conquista de Andalucía a través de la historiografía europea de la época”, in Andalucía entre Oriente y Occidente, 12361492 (Cordoba, 1988), pp. 37-49; Muhammad Benaboud, "La caída de Córdoba según las fuentes andalusíes”, ibid., pp. 71-77.
} 
Much more might have been expected when the victorious King Ferdinand III accepted the surrender of Seville after subjecting it to a long siege, given that it was the recovery for Christianity of what had been the principal Visigothic see and, until the arrival of the Muslims in the Iberian peninsula in 711, the metropolis totius Hispaniae in the time of Isidore of Seville. That the conquest of Seville by the armies led by King Ferdinand III was arduous is very clear from the documents issued by the royal chancery during the long months of the siege of the city. In July 1247 the Castilian king granted the Order of Santiago a licence to populate some properties in the north of the kingdom, in Zamora. For the first time a document was issued in exercitu prope Sibillam. ${ }^{10}$ From that moment until 24 November 1248 the chancery included the siege of Seville in the dating of the diplomas as the place where the king, his court and officials were to be found. On 24 November, a document was dated in the city of Seville. The Christian king had finally conquered the Almohad capital.

The first royal document in which King Ferdinand III added to his titles that of King of Seville is a letter to James I of Aragon concerning the marriage of their respective offspring, the future Alfonso $\mathrm{X}$ and Violante of Aragon. Justifying what seems to be a refusal to celebrate it immediately, he says: “...considerati debetis vos in quo loco sumus et quam elongati sumus a terra et regno nostro". He goes on to explain that his presence, and that of his nobles and knights, cannot be spared in hac nova acquisitione Sibille. ${ }^{11}$ That the exact date of the conquest was not recorded in the document, nor remembered in subsequent years, as had happened after that of Cordoba, is probably because of changes in the customs of Chancery on the death of the chancellor John of Soria, who had been the holder from the final years of the reign of Alfonso VIII to 1243.

Surprisingly, an event so laden with political and ecclesiastical significance received less attention than the conquest of other places of much less importance. In the case of Seville there were no witnesses of the events to immortalize the moment in the pages of a chronicle, as had the Archbishop of Toledo or the royal chancellor; there were no chancellors like John of Soria to recall its importance in the dating of royal documents; and, perhaps because of these absences, it did not have the same impact outside the

${ }^{10}$ Reinado y diplomas de Fernando III, 3.doc. 747, 312-313.

${ }^{11}$ Ibidem, doc. 769, 339-340 
Iberian peninsula that the conquest of Cordoba had in the Christian world. The construction of the narrative of the conquest of Seville was not, as with Cordoba and the Christian victory in the Navas, contemporary with the events themselves.

The enormous importance that the conquest of Seville would acquire in the Hispanic imagination in the late medieval and early modern period - even greater than that of Cordoba which was perhaps more decisive in the eyes of its actors and more widelyknown at the time - in fact had much to do with the story developed in the Estoria de España of Alfonso X the Wise, one of the fundamental texts composed in the so-called Alphonsine historiographical workshop, ending with the story in extenso of the reign of Ferdinand III until his death in 1252, written seventy years later, in about the 1320 s. $^{12}$ The main sources used by the Alphonsine compilers, in particular the Chronicon Mundi of Luc of Tuy and De Rebus Hispaniae by the Archbishop of Toledo, stayed silent after the conquest of Cordoba, and since there were no surviving direct witnesses of such significant events as the conquests of Jaen, Seville and the territory in the valley of the Guadalquivir, a new text was added to the Estoria de España. Here the conquest of Seville was given particular importance, thus establishing the master narrative which would not be omitted from the chronicles written until modern times, nor in the histories produced in Seville which were taken as the basis of the process of canonization of Ferdinand III in the seventeenth century. ${ }^{13}$ The conquest of Seville thus acquired, from the early fourteenth century onwards, an importance in the construction of the account of the Christian re-conquest that it had not enjoyed in its own day.

Of the ninety-six chapters devoted to the reign of Ferdinand III in the Estoria de España, fifty-five are centred on the siege and fall of Seville. The siege, according to this account, lasted seventeen months, starting in the summer of 1247 . Between the

\footnotetext{
${ }^{12}$ Ramón Menéndez Pidal, Primera crónica general: Estoria de España que mandó componer Alfonso el Sabio y se continuaba bajo Sancho IV en 1289 (Madrid, 1906). In addition to the complexities inherent in the Estoria de España, Menéndez Pidal's edition lent the text a homogeneity and deliberate consistency totally at odds with the process of composition. Diego Catalán, La Estoria de España de Alfonso X. Creación y evolución (Madrid, 1992); Inés Fernández-Ordóñez, Las 'Estorias' de Alfonso el Sabio (Madrid, 1992); Alfonso X el Sabio y las Crónicas de España, ed. Inés FernándezOrdóñez (Valladolid, 2001),

13 Ana Rodríguez, "Fernando III el Santo (1217-1252): Evolución historiográfica, canonización y utilización política”, in Miscel.lània en Homenatge al P. Agustí Altisent (Tarragona, 1991), pp. 573-588.
} 
laying of the siege and the surrender of the city by its inhabitants, there appear all kinds of episodes and anecdotes: from the arrival of the nobles and the armies of the Military Orders, the strategies of the attackers to undermine the resistance of those trapped in the city, the felling of trees and burning of natural resources, and skirmishes with the warriors, up to the pact made with some of the surrounding Muslim towns. In addition it includes noble and chivalrous deeds that may have come from sources now lost.

The siege of Seville obliged a large part of the nobility and concejos of the realm to serve the king and to remain in the Christian camp with their armies. It was the Military Orders, whose masters accompanied the king throughout the campaign, charged with the protection of strategic sectors of the Castilian camp, and the municipalities nearest the frontier who took the most active part in the Seville campaign. On 23 November 1248, more than a year after the arrival of the Christians at the gates of Seville, the city surrendered, its inhabitants exhausted and starving. The Muslims of Seville handed the city over to the Castilian king. They were given a month to sell their property and to leave the city. On the feast of the Translation of St Isidore, a date of extraordinary symbolic value for its commemoration of the ecclesiastical and cultural greatness of the Visigothic period, a solemn procession headed by Ferdinand III entered the former mosque, baptized as the church of St Mary. Afterwards, according to the Estoria de España, the king established the patrimony of the church and restored the archiepiscopal see of the time of Isidore of Seville, organized the city, populated it, awarded land and other goods to the Military Orders, to the knights, to the princes and wealthy men, divided up the region of the Aljarafe and had it populated and worked by people from many different places, to whom he granted freedoms and privileges ${ }^{14}$. In other words, he took the steps necessary to finalize what had been a great conquest with a complex process of colonization.

(ii) Repartimiento, settlement and immigration

In 1253, the year after his accession to the throne and five years after his victorious father had entered Almohad Seville, King Alfonso X gave the Libro del Repartimiento - "Book of Apportionment" - to the city. The model of apportionment was not new.

\footnotetext{
${ }^{14}$ Processes discussed in Robert Bartlett, The Making of Europe: Conquest, Colonization, and Cultural Change, chapter VII.
} 
Probably tested in the distribution of land and booty that took place after the conquest of cities and their surrounding regions in the preceding centuries, it had been adapted to the new reality of providing inhabitants for the vast lands conquered by Castile and Aragon during the thirteenth century. ${ }^{15}$ The immediate objective of the Libros de Repartimiento was the handing over of town and rural property to the beneficiaries of the conquest. However, it is far more important than a mere process of population, for the books record not only the property granted to those who came to inhabit the land from the north of the kingdom or from the borderlands, but also ex gratia donations given to the king's family, the nobility and the Church as a share of the spoils gained in conquest. There is no record of how many Libros de Repartimiento may have been written during the thirteenth century. Only six have been preserved, all of them corresponding to different towns of the Almohad kingdom of Seville; it seems, however, reasonable to think that their writing was more widespread.

The Repartimiento de Sevilla is the most extensive and complicated. ${ }^{16}$ The parcels of land were distributed using the twin criteria of the size of the holdings and the social position of the beneficiaries. The relatives of Alfonso $\mathrm{X}$ - the queens, the infantes of Castile, Portugal and Aragon -, the great nobles and members of the royal court, the bishops, and the masters of the Military Orders were the recipients of rural properties of enormous size, with a variety of crops; these were the so-called donadíos mayores, or major gifts. The military nobility who had taken part in the conquests alongside the king, knights of lower rank, such as the mounted crossbowmen of King Ferdinand III as well as a group of Catalan crossbowmen, motley royal servants, the entourages of the queens and some monasteries, as well as a numerous group of Muslim alfaquíes and Jews - who possibly had granted the king loans for the campaigns - received smaller

\footnotetext{
${ }^{15}$ The sophistication of structure and concepts shown by the different surviving libros de repartimiento leads one to think of precedents whose origins may be found in the conquests of Toledo and Zaragoza. Manuel González, "Repartimientos andaluces del siglo XIII: Perspectiva de conjunto y problemas", Historia, Instituciones y documentos, 14 (1987), 103-122; idem, "Frontier and Settlement in the Kingdom of Castile (10851350)", in Medieval Frontier Societies, ed. Robert Bartlett and Angus MacKay (Oxford, 1992), pp. 49-74.

${ }^{16}$ Julio González, Repartimiento de Sevilla (2 vols; Madrid 1951). There are two surviving versions, both from the fourteenth century. The whole of the apportionment of the city of Seville has not survived, and neither has the complete list of inhabitants; it is not known how many knights, infantrymen or simple colonists initially took part in the repopulation of Seville.
} 
parcels of land producing cereals, olives, and figs, or houses and mills; these were the so-called donadíos menores, or minor grants. Albeit indirectly, the record of the granting of the donadíos provides valuable information not only about the organization of the holdings but also about military strategy and its consequences for the land. In general, the grants were of rural properties already under cultivation, where the existing Muslim workers would have been retained. Likewise, the reference to burned crops "thirty thousand feet of healthy olive and fig groves, and ten thousand burnt", for example, were granted in the location of Amarlos - suggests devastation as a tactic of the Christian armies during the siege of Seville.

In the city, the royal officials in charge of the distribution, accompanied by scribes (who wrote down to whom the lots were given, together with their size and location) and Muslim sabidores who knew the terrain well, parcelled out some of the neighbourhoods and gave them to settlers coming from very different parts of the kingdom. Properties were granted to, among others, 200 knights, with the proviso that they should populate the land and occupy the houses within two years. Some of them abandoned their properties shortly afterwards; when this happened immediately after the handover, the Libro de Repartimiento re-assigned the same lots to other knights coming from the northern territories, many of them relatives and vassals of those who already had benefited in the distribution. Finally, King Alfonso gave out properties for the maintenance of the cellars and royal storerooms and for the royal galleys.

The thirteenth-century repartimientos granted large estates to the Castilian nobility and some of the most important ecclesiastical institutions, bishoprics and monasteries of the kingdom. But the problems in populating these vast territories, where the number of Muslim peasants would have been significantly reduced, and the fact that many of the beneficiaries had not given up their possessions in their places of origin when they answered the royal summons, caused a considerable number of those who had benefited in the distribution of land to abandon the property received from the king and to return to the towns and villages from which they came. A substantial proportion of the donadíos given to the military nobility and knights changed hands in a short time. As a result, in the fourteenth century it became necessary to proceed to a new redistribution 
of land in some regions that had lost their initial inhabitants. ${ }^{17}$ The surviving documentation reveals that some of the first beneficiaries of the divisions sold their properties shortly after receiving them, even though - at least in the properties established in the city - there was a specific condition that they could not change owners for five years, a condition clearly intended to ensure stability of the urban population and the consequent maintenance of economic life.

It is clear, however, that the rapid integration of Al-Andalus would have side effects. The extent of the consequences of the Christian conquest in the final years of the reign of Ferdinand III and the first decade of Alfonso X - soon after Seville, Jerez and the kingdom of Niebla fell into Christian hands after painful sieges - has been much debated. The emphasis has generally been laid on the disruption of the production systems of land in the north of the Castilian-Leonese kingdom from the second half of the thirteenth century, and on the fact that the repopulation of the Andalusian territories sparked a southward migration of peasants from north of the border. The decline in population experienced since the late thirteenth century as a consequence of the conquest of Andalusia, exacerbated by the expulsion of the Mudejars in 1264 after their revolt against Alfonso $\mathrm{X}$, would thus add a local factor to the crisis felt in all its harshness throughout Europe in the middle decades of the fourteenth century. ${ }^{18}$

Although the relationship between the policies of population settlement and the economic crisis is more complex than this interpretation implies, it is clear that it concerns a fundamental problem: to understand how such a vast conquered territory could be organized in so short a time. Little is known, however, of those who were not recorded individually in writing as beneficiaries in the division of Seville. Some of them

\footnotetext{
${ }^{17}$ Manuel González, En torno a los orígenes de Andalucía. La repoblación del siglo XIII (Seville, 1988); idem, La repoblación en la zona de Sevilla durante el siglo XIV (Seville, 1993).

18 Teofilo Ruiz, Crisis and Continuity. Land and Town in Late Medieval Castile (Philadelphia, 1994); idem, Las crisis medievales, (1300-1474), (Barcelona, 2007). For Ruiz, the depopulation caused by the Black Death in 1348, a century after the conquest of Seville, was just one more factor added to a problem that already existed. This point of view, however, has received considerable criticism from Spanish scholars. On this, see the cited works by M. González and Ruiz's own clarifications in Sevilla, 1248 (Madrid, 2000). A new approach in a general Iberian context in Ana Rodríguez, "Spain", in Agrarian Change and Crisis in Europe, 1200-1500, ed. Harry Kitsikopoulos (New York, 2011), pp. 167-203.
} 
probably stayed in the city and its surroundings, but others returned, immediately or shortly after, to settle their debts or to recover the lands that they may have had to mortgage in their regions of origin. This is to a large extent hypothesis and conjecture, since the scraps of information available only allow us to glimpse the impact that the Christian conquest of the great cities of Al-Andalus had on the northern territories of the kingdoms of Castile and Leon between the decades of 1230 and 1260, and the transformations that it produced. Nor is it easy, finally, to determine whether the local nobility, knights and other servants of the high nobles and bishops and archbishops consciously became involved in a process of conquest capable of generating a strong Christian identity; or whether they were simply meeting the onerous feudal obligations to which they were subject, and hoping to receive some benefit from them.

The regions that had been closest to Al-Andalus in the twelfth century were, by the first decades of the thirteenth, very far from the frontier areas. Those where it was hardly possible to remember the presence of the Muslims, for example in the north of the kingdoms of Castile and Leon, had already been distanced from the phenomenon of conquest for two centuries. Nevertheless, however distant the military campaigns being waged by the kings on the frontiers of Al-Andalus might seem, their repercussions on monastic domains, on the property of minor noble houses on a local scale, and on the chains of dependence in the local world, would have been extraordinarily important by the time of one of the greatest of Christian conquests, that of the city of Seville in 1248. A change in the scale of the subjects under analysis, from solemn events in the kingdom to everyday life in the small worlds, from great narratives to monastic charters, enables us to approach these issues with new perspectives, involving a higher number of actors.

(iii) Last wills and poor expectations

In his Vie de Saint Louis, Jean de Joinville gave details of his preparations for what would be the earliest crusade of Louis IX of France, and of the consequences that the royal expedition had on his estates in the Champagne region. In common with many other French knights, Joinville summoned his vassals at Easter 1248 - probably while Fernando III was organizing the campaign leading to the conquest of Seville in November of that year - to announce to them that he was going to set off for the Holy 
Land with his lord the king. He then proceeded to settle some issues in his lands, dealing with grievances that the nobles had brought him: he did not wish to leave after causing harm to anyone, although it is possible that this settlement also sought to avoid conflict in his territory during his absence. Then he went to the city of Metz to borrow money against his territorial heritage, which - he confessed on the eve of starting the journey to the Holy Land - brought him barely a thousand pounds, because his mother was still alive and enjoying some of their resources. He was able to gather a modest force, a group of nine knights, to which were added two more to carry his banner. With a neighbouring count, who was also going to the Holy Land accompanied by nine knights, he rented a ship to travel from Marseille. When he reached Cyprus to join Louis IX, having paid the cost of transport he had only 240 pounds left. The knights who accompanied him threatened to leave him unless he obtained more money to meet the expenses of the crusade. Then, as a grateful Joinville recounts, the King of France came to his aid, taking 800 pounds from his treasury and handing it to Joinville. ${ }^{19}$

Any Crusader leaving for the Holy Land in the twelfth and thirteenth centuries had to face a similar situation: to find the money needed to meet the expenses of the expedition, to safeguard their assets and to ensure the interests of their families. Some testimonies have survived recounting the activity generated thereby: its protagonists, who sold or pawned their lands; its beneficiaries, the local monasteries or knights who took the opportunity to increase their wealth; the repayment conditions imposed; and the consequences it caused in the medium term, when the Crusaders returned after a few years, if indeed they ever did. Joinville went to the city market to pawn his lands. Elsewhere, a register kept at the Abbey of Abingdon detailing the sales and pledges of the lands of Hugh, a knight from Berkshire who joined the crusades in about 1247, reveals the role played by ecclesiastical institutions as well as the impact of transactions on the local land market and on the regional lordship structure. The return from Egypt of Guy de Lusignan at Christmas 1250, told in detail by Matthew Paris, shows the hardship sometimes faced by Crusaders and the difficulty they encountered in enforcing the agreements that they had reached before their departure from England, in this case with the Abbot of Faversham. As with Joinville, it was the king, in this case Henry III,

\footnotetext{
${ }^{19}$ Jean de Joinville, Vie de Saint Louis, ed. Jacques Monfrin (Paris, 1998), (110-113), 56-58 and (133-136), 66-67. Robert Bartlett has dealt with the relationship of the Joinville family with the Crusades from 1147 in The Making of Europe.
} 
who had to come urgently to the aid of his half-brother Guy, providing him with land and goods. $^{20}$

In this aspect, the way in which lords, great and small, had to bear the expense of the Christian military campaigns in Al-Andalus was very similar. The conquest of Seville again provides an excellent overview of what was involved in the mobilization of men and resources to deal with the enormous conquering momentum of the middle decades of the thirteenth century. In the long months of the siege of Seville, the seigneurial armies continued to join the royal camp. Juan Arias, Archbishop of Santiago, did so in the spring of 1248. Although he is the only prelate whom the Estoria de España shows in command of his armies in Seville, the Archbishop did not play a prominent role in the siege: he fell ill upon arrival, or perhaps was already ill, and had to withdraw unceremoniously soon after. ${ }^{21}$ Although nothing is said, it is reasonable to assume that the troops who accompanied him returned with him to Galicia. Their number - in contrast to the scant dozen knights brought by Joinville to the Crusader armies of France - must have been high, since they even formed their own camp. ${ }^{22}$

Who made up this army that accompanied the archbishop to Seville? Although the Estoria de España does not give details, they would be knights from the area of Compostela. Some of them were able to benefit from the Repartimiento of Seville, although their varying status was reflected in the type of endowment they received. Don Rodrigo Gómez of Galicia, a member of the line of the counts of Traba, won a donadío

${ }^{20}$ For these and other cases in England, see Simon Lloyd, "Crusader Knights and the Land Market in the Thirteenth Century”, in, Thirteenth-Century England, II, Peter R. Coss and Simon D. Lloyd, 119-136.

21 ،...ueyendo el rey en como estaua muy flaco, mandolo tornar para su tierra et que punnase en guarescer et en pensar de si. Et el arçobispo ouolo de fazer, et fuese ende, pesandol mucho. [... the king, seeing that (the archbishop of Santiago) was very thin, ordered him to return to his land and to strive to recover and to think of himself. And the archbishop had to do so, and went from there, greatly distressed.]' Chapter 1117.

${ }^{22}$ It has been estimated that Ferdinand III's retinue consisted of 200 knights and crossbowmen, the forces of the ricoshombres and of the infantes of 2000 knights and between 6000 and 8000 foot-soldiers, while the Military Orders provided 150 friars, 150 knights and 400 foot-soldiers. To these must be added the fighters from the municipal militias and those accompanying the bishops and nobles, whose number is difficult to estimate. In total, the number of participants in the siege and conquest of Seville may have ranged between 3000 to 4000 horsemen and 8000 to 10,000 infantry. Francisco García Fiz, "El cerco de Sevilla: reflexiones sobre La guerra de asedio en La. Edad Media”, in Sevilla 1248 (Madrid, 2000), pp. 115-154. 
mayor in Cerraja, which he named Trastamar - the place from which his family originated - and arable land in a place called Corán. Like the majority of the great aristocrats who accompanied the king, he certainly did not actually settle there. Velasco Fernández de Ambía and García Pérez de Ambía received donadíos menores in a place called Mesnada, which was handed over to the Leonese retinues (mesnadas in Spanish) of King Alfonso X. They both returned to their properties in the region of Orense in the following years, as can be deduced from the fact that in 1274 they received the loan of places and houses in Allariz belonging to the monastery of Melón. ${ }^{23}$ The Archbishop of Santiago too, despite his unsuccessful participation in the conquest, received a donadío mayor in the Repartimiento, which he called - as was to be expected - Santiago. No other Galician bishop received any grant in the area of Seville; nor did the municipalities of the region, which had been absent - unlike the majority of those of the kingdom - from the siege of the Almohad capital. ${ }^{24}$

From the information provided both by the Estoria de España on the conquest of Seville and by the Repartimiento of the city it is difficult to form an idea of the magnitude of the recruitment conducted by the great nobles and prelates who participated with the king in the conquest of Al-Andalus. However, valuable information on the local impact of mobilization comes from the monastic archives of the north of the Iberian Peninsula, which have preserved a number of wills of knights and minor local nobility from the second half of the thirteenth century, mostly written between 1250 and 1270. Throughout these decades, the conquering momentum of the Christians continued. Castile took over the countryside around Seville and the Muslim kingdom of Niebla; at the same time the conflicts between Alfonso X and the Castilian nobility acquired a prominence that they had not had in the reign of Ferdinand III. Some of these wills provide an insight into the logistics of the Cordoba and Seville campaigns, for instance the call to arms in late winter to reach the royal camp in spring.

${ }^{23}$ Pablo Otero Piñeyro and Xosé Antón García, “Apuntes de los Ambía: linaje y parentelas (siglos XII-XVI)”, Cuadernos de Estudios Gallegos 56 (2009), 445-457.

${ }^{24}$ In June 1248, from the siege of Seville and in dire need, Ferdinand III asked for an extraordinary loan from the Galician municipalities of 5\% of the assets of each of them. This was probably the reason for their exemption from the obligation to provide military aid. This task had been assigned to the royal porter Domingo Pérez of Toro who between 1245 and 1251 collected almost 150,000 maravedis. Reinado y diplomas de Fernando III, 3.docs 765 and 829. He was finally rewarded in the Repartimiento of Seville as a member of Ferdinand III's household. 
Thus in March 1236 a knight undertook to hand all his possessions and three mares to the monastery of Santo Toribio in Liebana si io finare in la oste ("if I should die in the army”), probably referring to the Cordoba campaign . In March 1248, cuando yva a la hueste de Sevilla ("when going to the army in Seville"), another knight listed the debts he had incurred with the Leonese monastery of Otero de las Dueñas. ${ }^{25}$

Other wills reveal that the mobilization of people and resources to answer a royal call, such as that in Seville, was not the only circumstance in which it was necessary to summon the feudal armies: there were minor campaigns against the Muslims of $\mathrm{Al}$ Andalus, not mentioned in the chroniclers' stories; continuous activity in the royal court, which the king's closest advisers had to attend; and clashes between factions of nobility, and of these factions against the king. This meant that the need to address military spending was more important than implied by the narrative of Christian expansion in the chronicles of the time, or even in documents issued by the Castilian royal chancery.

The chain of dependencies reached places most remote from the scenes of the conquest of Al-Andalus. One, recorded among the documents of the Cistercian monastery of Oseira (Galicia), started in the heart of Orense, reached to the see of Compostela, and from there went to the countryside of Seville in the years after the conquest of the city. In 1251, Diego Garcia, an armiger, obliged to accompany his master to Seville, borrowed 300 sueldos from the monastery of Oseira, giving as guarantee a piece of land, which the monastery would inherit if he died during the expedition. ${ }^{26}$ The master of this squire, as we can deduce from contemporary evidence, was a member of the local minor nobility, tenant of a place known as Tabulata. In February 1254, before leaving for Castile, Arias Pérez, a knight from Tabulata and probably a relative of the said tenant, stipulated in the first of his three surviving wills his desire to be buried in Oseira, pawning some goods that would become monastic property if he died - quod si forte obiero in terra ad quam in presente equito - and would pay for his malfetrías

\footnotetext{
${ }^{25}$ Cartulario de Santo Toribio de Liébana, ed. Luis Sánchez Belda (Madrid, 1948), doc. 145; Colección documental del Monasterio de Santa María de Otero de las Dueñas, ed. José Antonio Fernández Florez and Marta Herrero de la Fuente (León, 1999), 2.doc. 577.

${ }^{26}$ For this and the following documents, see Colección diplomática del monasterio cisterciense de Santa María de Oseira (1025-1310), ed. Miguel Romaní (Santiago, 1989), 1.docs 670, 683, 718, 790 and 876. Volens ire in exitu Hispalensi, pergere cum domino meo I. Egidii ad Sibillam, pergens ad Castellam, are the formulae used.
} 
(misdeeds) and his debts. He also took care to see to the organization of the family assets, widely dispersed and partly consisting of undivided properties. Arias Pérez did not die during the campaign. In May of the same year he had another will prepared, for he had to leave again. The complexity of the assets to be organized, together with the need for money to finance a new expedition, probably obliged him to do so. In 1257 he wrote his third will, before setting off for Castile to attend the royal court. The terms of the will were reminiscent of the previous ones. Some of the agreements reached between the knight of Tabulata and the monastery of Oseira in the previous decade were renewed for the last time in $1260 .^{27}$

Within a period of five years, this knight of Tabulata had three times undertaken journeys - from all of which he had returned - in order to comply with his military obligations. Other nobles of the area undoubtedly found themselves in similar situations, such as the knight Juan López, who before leaving for Seville in about 1250 made a will bequeathing property to the Oseira monastery, where he asked to be buried, and handing over 400 sueldos to compensate for his malfetrías in the kingdom of Portugal. ${ }^{28}$ Squires like Diego García were members of the entourage of the tenant of Tabulata. Relatives of the latter, such as Arias Pérez, followed nobles of higher status. The knight Pelayo Fernández of Rodeiro, one of the most powerful nobles of the region - one of his brothers was the royal merino or bailiff - had the first of his three wills written in October 1255 when he answered the summons of King Alfonso X. Immersed in a family dispute, he put his assets under the protection of the monastery of Oseira. Among the witnesses was Arias Pérez, knight from Tabulata. In the same year, Pelayo Fernández of Rodeiro confirmed the will made shortly before, this time because he had to join the king's army by order of his lord the archbishop. He cannot have got very far. Shortly afterwards, while ill in Santiago, he had his third will prepared. He left some property to the monastery of Oseira and some to the church in Compostela, confirmed what was due to his brothers, and made a payment to compensate for his misdeeds. He then proceeded to list his debts: he owed 500 sueldos for the military campaigns in

\footnotetext{
${ }^{27}$ In 1264 Arias Pérez was still very much alive: on 8 July he established the dowry of land and property in different places that his wife should receive. On 9 July he sold to the Archdeacon of Lugo precisely the same goods that he had supposedly handed to his wife only one day before. Ibid., 2.docs 911 and 912.

${ }^{28}$ Ibid., 2.doc. 645.
} 
Tierra de Campos accompanying the archbishop of Santiago, as well as 200 sueldos for the debts inherited from his father. ${ }^{29}$

A chain of obligations linked a squire of a small village in Orense with the king of Castile and with the military campaigns being carried out over 800 miles away, and no less than ten days' journey on horseback. In 1251, the squire had to accompany his lord to Seville and therefore got into debt with the monastery of Oseira, using his land as guarantee. A knight of Tabulata, probably a relative of the lord of the armiger, before leaving for Castile, stipulated the giving of part of his property to the monastery if he were to die in distant lands. In the same terms he made two more wills in the space of five years. The aim, besides obtaining new cash loans to defray the costs of the journey, buying a horse and renewing his weapons, was to renegotiate his debts and to appoint the creditor monastery as the manager - and in time, as the owner - of a complex estate, and as guarantor of the rights of his underage children. ${ }^{30}$ The knight of Tabulata was in his turn obliged to accompany the lord of Rodeiro, member of a powerful noble family of the region. The latter made three wills in 1255, before joining the royal army with the Archbishop of Santiago. In the last of these he organized the family assets, gave goods to the monastery of Oseira, and revealed the high amount of his debts. Archbishop Juan Arias of Santiago, finally, also had to face the costs of the military campaigns against the Muslims of Al-Andalus. As well as his unsuccessful involvement in the siege of Seville, he may have been present at others for which we have no narrative such as that preserved in the Estoria de España. To our knowledge, of them all - the squire, the two knights of different social status, and the Archbishop of Santiago - only the last was

${ }^{29}$... quando ivi ad dominum regem per mandatum et vocationem ipsius, ... quando volui ire de mandato domini mei archiepiscopi ad exercitum domini regis. Colección diplomática del monasterio cisterciense de Santa María de Oseira (1025-1310), ed. Miguel Romaní (Santiago, 1989) 2. docs 742, 745 and 748.

${ }^{30}$ Ana Rodríguez, "Monastic Strategy and Local Relations: the Social Influence of the Monastery of Oseira in the Thirteenth Century", in Reyna Pastor et al., Beyond the Market: Transactions, Property and Social Networks in Monastic Galicia. 1200-1300 (Leiden, 2002), pp. 165-236. In practice, and only ten years after the first will, the older children of Arias Pérez had lost the rights over the properties of their father in favour of a minor under the guardianship of the monastery of Oseira. On recourse to mortgage in the region of Gascony and its possible relation to the Spanish Reconquest, see Constance Hoffman Berman, "Land Acquisition and the Use of the Mortgage Contract by the Cistercians of Berdoues”, Speculum 57 (1982) 250-266. 
rewarded in the royal distribution of loot and wealth listed in the Repartimiento of Seville.

The indebtedness of these gentlemen resulted not only from their participation in campaigns against the Muslims of Al-Andalus. In 1255 Pelayo Fernández of Rodeiro had to prepare his military contingent to go to Tierra de Campos, on the former border between León and Castile, the scene of conflicts among royals and nobles since the early decades of the thirteenth century. In December of the previous year, another noble from the area of Oseira made a will before leaving for the war between Diego López of Haro and Gonzalo Nuñez of Lara, instituting a legacy to pay for the malfetrias he had committed in Portugal. Between 1230 and 1240, the wills of Galician knights reveal that the places they went to war could just as well be Tierra de Campos and other places in the kingdom of Castile as the border of Al-Andalus.

The calls to arms - of the great lords, of the Archbishop of Santiago - must have been very frequent in the middle decades of the thirteenth century. There are therefore no perceptible sudden changes in social relationships or in the ownership of land, or at least not the same attested by the evidence of the wills of the Crusaders who at the time had to sell or pawn part of their property to embark for the Holy Land. However, a debt that became habitual in the medium term might end by transforming relations between the families of the knights and ecclesiastical institutions - such as the monastery of Oseira which acted as money-lenders, and with which links were created that would last over time, and would be renewed and renegotiated far beyond the purely economic aspect.

For the local nobility whose family wealth was concentrated in the northern kingdoms and whose interests were totally unrelated to the dynamics of the border, the acceleration of the conquests in Al-Andalus during the reign of Ferdinand III and in the early years of that of Alfonso X created only low expectations, and provided no great benefit. Nothing in the wills preserved in monastic archives can confirm that the aspirations of those who had them drawn up went beyond obtaining enough liquidity to undertake the forced journey, and some reasonable assurance that their frequent absences would not complicate the management of their widely-dispersed heritage, shared among several members of the same family. Although potential profit obviously came into the calculation of the knights, in practice their expectations had to be limited 
to the possibility of renegotiating loans and not falling into social decline, which could be an unintended consequence of the expenses and debts incurred. ${ }^{31}$ What we do glimpse, however, is the socialization at the local level of certain political processes that were taking place in a world that was distant both spatially and mentally. And this is usually not something easy to find. The great military achievements related and amplified by the chronicles of the time conditioned not only the day-to-day experiences of the Galician knights and the forms of relationship among them, but also the links with the ecclesiastical institutions around them - institutions which sometimes ended up controlling the assets that had been placed under their custody.

The religious expansion of Latin Christendom between the eleventh and fourteenth centuries did not always take place through a process of conquest and immigration, but this was often the case, as in the words of Robert Bartlett with which this article began. Seen from the north of Iberia in the mid-thirteenth century, the rapid Christian conquest begun with the battle of Las Navas in 1212 and culminating with the fall of Seville in 1248 at the hands of the armies of Fernando III represented one of the moments of greatest expansion of Latin Christianity through military conquest: it involved the extensive use of large contingents from all corners of the kingdom and inaugurated a process of colonization whose scope and consequences are difficult to determine. The view from the heart of a region involved in costs, but far removed from benefits, sheds light on the inequality of expectation, the weight of obligation, and the chain of dependency in the local context; as well as on the economic and social impact of the almost permanent mobilization that must have taken place during these decades. It also reveals that ultimately the rhetoric of war against the infidels, in Al-Andalus just as in the Holy Land, that fired up the discourse of the narrative sources of the period, would probably have been pretty meaningless for the life experience of those anonymous knights and squires who, in the spring of 1248, accompanied an archbishop of Santiago, perhaps already sick, on his way to the royal camp set up at the gates of Seville.

\footnotetext{
31 The calculation did not always turn out well: in 1224 one of them, not having received any benefits from King Alfonso IX of León, had joined the struggle of Count Gonzalo Núñez de Lara against Fernando III, king of Castile. He regretted the decision, but had been unable to break the engagement. He therefore left the management of his assets to the Galician monastery of Lorenzana. Ángel Rodríguez and José Ángel Rey, "El Tumbo del Monasterio de Villanueva de Lorenzana", Estudios Mindoniensis 8 (1992), 11-324, doc. 118.
} 